\title{
The Effect of Switch Treatment on Liver Fibrosis and qHBsAg Levels in Patients with Chronic Hepatitis B
}

\author{
Kronik Hepatit B Hastalarında Switch Tedavisinin Karaciğer Fibrozu ve qHBsAg \\ Düzeylerine Etkisi
}

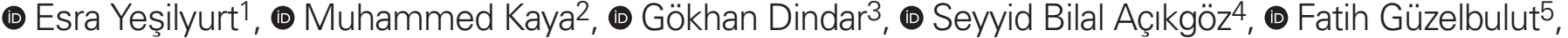 \\ (1) Hayrunnisa Sezikli6, (1) Göktuğ Şirin7, (1) Mesut Sezikli8
}

${ }^{1}$ Karabük State Hospital, Clinic of Internal Medicine, Karabük, Turkey

2 Hitit University Çorum Erol Olçok Training and Research Hospital, Clinic of Internal Medicine, Çorum, Turkey

${ }^{3}$ Kocaeli Derince Training and Research Hospital, Clinic of Gastroenterology, Kocaeli, Turkey

${ }^{4}$ Ondokuz Mayıs University Faculty of Medicine, Department of Rheumatology, Samsun, Turkey

5/stanbul Haydarpaşa Training and Research Hospital, Clinic of Gastroenterology, Istanbul, Turkey

${ }^{6}$ Hitit University Çorum Erol Olçok Training and Research Hospital, Clinic of Biochemistry, Çorum, Turkey

${ }^{7}$ Kocaeli University Faculty of Medicine, Department of Gastroenterology, Kocaeli, Turkey

8Hitit University Çorum Erol Olçok Training and Research Hospital, Clinic of Gastroenterology, Çorum, Turkey

\begin{abstract}
Objectives: The aim of this study was to evaluate the relationship between clinical, biochemical, serological parameters, fibroscan imaging in terms of fibrosis and quantitative hepatitis $B$ surface antigen (qHBsAg) levels in patients with chronic hepatitis $B(C H B)$ infection whose treatment has been switched from LAM to TDF. Materials and Methods: The study included 19 patients with $\mathrm{CHB}$ and under the LAM treatment. The gender, age, comorbidity, medications, routine laboratuary, creatinine clearance, bone mineral density, transient elastography for stage of liver fibrosis and qHBsAg level were examined.

Results: Ten of 19 patients were female and 9 were male. When the qHBsAg titers of the patients at $6^{\text {th }}$ and $12^{\text {th }}$ months were compared, there was a statistically significant decrease in qHBsAg titers of the patients after the $12^{\text {th }}$ month. There was a significant decrease in liver fibrosis measurements at the $12^{\text {th }}$ month of treatment change. There was a statistically significant positive correlation between qHBsAg titers and fibroscan values at baseline and $12^{\text {th }}$ month.
\end{abstract}

\section{ÖZ}

Amaç: Bu çalışmanın amacı, tedavisi LAM'den TDF'ye geçen kronik hepatiti B (KHB) enfeksiyonu olan hastalarda klinik, biyokimyasal, serolojik parametreler, fibroskan görüntüleme ile fibrozis ve kantitatif hepatit B yüzey antijeni (qHBsAg) düzeyleri arasındaki ilişkiyi değerlendirmektir.

Gereç ve Yöntemler: Çalışmaya LAM tedavisi altındak 19 KHB hastası dahil edildi. Cinsiyet, yaş, yandaş hastalıkları, ilaçlar, rutin laboratuvar tetkikleri, kreatinin klirensi, kemik mineral dansitesi, fibrozis derecelendirmesi için transient elastografi ölçümü ve qHBsAg seviyeleri belirlendi.

Bulgular: 19 hastanın 10'u kadın 9'u erkekti. Hastaların 6. ve 12. ayındaki qHbsaq titreleri değerlendirildiğinde, 12. ayın sonunda qHBsAg titrelerin anlamlı ölçüde düşüş saptandı.

Karaciğer fibrozis ölçümlerinde de tedavi değişikliğinin 12. ayında anlamlı düşüş saptandı. Başlangıçtaki ve 12. aydaki qHBsAg titreleri ile fibroscan ölçümleri arasında istatistiki olarak anlamlı bir pozitif korelasyon saptandı.

Yeşilyurt E, Kaya M, Dindar G, Açıkgöz SB, Güzelbulut F, Sezikli H, Şirin G, Sezikli M. The Effect of Switch Treatment on Liver Fibrosis and qHBsAg Levels in Patients with Chronic Hepatitis B. Viral Hepat J. 2020;26:69-73. 
Conclusion: In this study, the replacement of LAM with TDF may prevent the resistance problem, and also the decrease in fibrosis values and/or qHBsAg levels may contribute to the prevention of $\mathrm{HCC}$ and cirrhosis have been showed.

Keywords: Lamivudine, tenofovir, switch treatment, liver fibrosis, hepatitis B
Sonuç: Bu çalışmada LAM yerine TDF'ye geçilmesi ile direnç probleminin çözülebileceği, aynı zamanda qHBsAg titrelerinde ve fibrozis değerlerinde düşüş sağlanarak HCC ve sirozdan da korunulabileceği gösterilmeye çalışılmıştır.

Anahtar Kelimeler: Lamivudin, tenofovir, tedavi değişikliği, karaciğer fibrozis, hepatit B

\section{Introduction}

Chronic hepatitis $\mathrm{B}(\mathrm{CHB})$ virus infection is the most common cause of cirrhosis, end stage liver disease, hepatocellular carcinoma (HCC) and death from liver disease in Turkey. Since long term suppression of HBV replication with antivirals is associated with histological improvement, the main goal of therapy for $(\mathrm{CHB})$ is to suppress HBV replication in a sustained fashion and thereby to prevent progression to cirrhosis and development of HCC. Currently, there are 2 classes of drugs approved for the treatment of CHB: pegylated interferon alfa and nucleot(s)ide analogues, i.e. lamivudine, adefovir, entecavir, tenofovir and telbivudine.

Lamivudine is the first nucleoside analogue for the treatment of $\mathrm{CHB}$. Lamivudine has been shown to be effective in patients with hepatitis $\mathrm{B}$ e antigen $[\mathrm{HBeAg}(+)]$ and $\mathrm{HBeAg}(-)$ chronic HBV infection whether they had compensated and decompensated cirrhosis $(1,2)$. In treatment naive patients with $\mathrm{HBeAg}(+) \mathrm{CHB}$, $\mathrm{HBeAg}$ seroconversion rates were shown to be $16-18 \%$ at year 1 (3).

In $\mathrm{HBeAg}(-) \mathrm{CHB}$, undetectable HBV-DNA levels were achieved in $60-70 \%$ of patients at year 1 ; however, HBV DNA became positive in $90 \%$ of patients after stopping therapy $(4,5)$. Lamivudine was also shown to prevent disease progression, HCC development, and the need for liver transplantation in compensated and decompensated cirrhosis $(6,7,8)$. However, resistance to lamivudine develops in $11-24 \%$ of patients with $\mathrm{HBeAg}(+) \mathrm{CHB}$ and $6-18 \%$ of those with $\mathrm{HBeAg}(-) \mathrm{CHB}$, and reaches up to $70 \%$ of patients after 8-year treatment (9)

Tenofovir is a potent nucleotide analogue with high genetic barrier to resistance (10). It is effective in both treatment naive and lamivudine/entecavir resistant chronic HBV infection (11). In $\mathrm{HBeAg}(+) \mathrm{CHB}$, tenofovir achieved undetectable HBV-DNA levels in $76 \%, \mathrm{HbeAg}$ seroconversion in $21 \%$, hepatitis B surface antigen $(\mathrm{HbsAg})$ seroconversion in $3 \%$, alanine aminotransferase (ALT) normalization in $68 \%$ and histological improvement in $74 \%$ of patients after 1-year therapy. In $\mathrm{HBeAg}(-) \mathrm{CHB}$, tenofovir achieved undetectable HBV-DNA levels in 93\%, ALT normalization in 76\% and histological improvement in $72 \%$ of patients after 1-year therapy (12). According to recently published EASL and AASLD guidelines, tenofovir is one of the first-line therapies for $\mathrm{CHB}(1,13)$.

In the present study, we aimed to evaluate the efficacy of tenofovir in chronic hepatitis B patients in whom serum HBV-DNA had become negative on lamivudine therapy and it was switched to tenofovir in the absence of lamivudine resistance with respect to biochemical and serological responses. We also aimed to evaluate the efficacy of tenofovir on liver fibrosis by transient elastography and associations of these variables with quantitative $\mathrm{HBsAg}$ (aHBsAg) levels.

\section{Materials and Methods}

The study included 19 CHB patients who had been followed up at gastroenterology outpatient clinic. Patients were screened for serum HBV-DNA, [aspartate aminotransferase (AST), ALT, alkaline phosphatase (ALP), gamma glutamyl transferase (GGT)], albumin, bilurubin, prothrombin time and creatinin levels. Of them, patients who were on lamivudine therapy and had undetectable serum HBV-DNA were included. $3 \mathrm{cc}$ blood samples were obtained from patients for the measurement of serum qHBsAg.

After centrifuged, serum samples were stored in deep freeze at $-80{ }^{\circ} \mathrm{C}$. At $6^{\text {th }}$ and $12^{\text {th }}$ months of therapy, same procedures were repeated. At the end of study period, serum qHBsAg levels were measured using Abbott Architect i2000sr device and Abbott ArchitectHBsAg 6C36 quantitative kit which was based on chemiluminescent microparticle immonoassay. Serum qHBsAg concentration $\geq 0.05 \mathrm{U} / \mathrm{mL}$ was considered positive. When qHBsAg was $>250.00 \mathrm{IU} / \mathrm{mL}$, serum samples were $1 / 500$ diluted.

Anti-HBc, anti-HBs, $\mathrm{HBeAg}$, and anti-HBe were measured using AbbottArchitect i2000sr device. Serum HBV-DNA was measured using Rotor-Gene Q, Qiagen device and Artus HBV QS-RGQ kit by real time polymerase chain reaction (PCR).

Serum and urine biochemistry tests were measured using Abbott/Architect C16000 device. Twenty four-hour urinary protein was measured by turbidimetric assay using benzethonium chloride as denaturating agent. Liver fibrosis was evaluated by transient elastography using CAP featured Fibroscan 502 Touch (SNF60121)Probe $\mathrm{xl}$ (SN90226)-c2.0.0.0 at the start and $12^{\text {th }}$ month of TDF therapy.

The liver stiffness measurement results were expressed in 1.5-75 $\mathrm{kPa}$ and CAP measurement results were expressed in 100$400 \mathrm{~dB} / \mathrm{m}$. Liver stiffness measurement was performed by one physician and factors that might hamper the liver stiffness were taken into account. More than 10 successful acquisitions, success rate $>60 \%$ and IQR/M rate $<30 \%$ were considered reliable.

Lamivudin was switched to TDF $245 \mathrm{mg}$ qd. Written informed concent was obtained form the all patients. Local Ethic Committee approval was taken from the Kocaeli University with the approval number of 21.91016-2016/15.2.

\section{Statistical Analysis}

Statistical analyses were made using SPSS ISPSS, Inc, Chicago, IL, USA) for Windows 17.0. For the evaluation of the study data, in addition to descriptive statistical methods (mean \pm standard deviation), the Student's t-test and the Mann-Whitney $U$ test were used to establish potential differences between the averages of two independent groups for parameters with and without normal 
distributions, respectively. One-Way ANOVA test and Friedman test were used for the comparison of dependent quantitative variables. Correlation analysis between quantitative variables were performed using Pearson correlation test. For comparisons of qualitative data, the chi-squared test was used. The results in the $95 \%$ confidence interval and $p$ values $<0.05$ were considered to be significant.

\section{Results}

The study included 19 patients. All patients were Caucasian, and 10 of them were $(52.6 \%)$ were female with a mean age of $54.7 \pm 9.6$ years. Eight patients $(42.1 \%)$ were smoker and none of them were alcohol drinker. Body mass index was $25.0-29.9 \mathrm{~kg} / \mathrm{m}^{2}$ in 9 patients $(47.4 \%), 30.0-39.9 \mathrm{~kg} / \mathrm{m}^{2}$ in 2 patients $(9.5 \%)$, and $\geq 40.0 \mathrm{~kg} / \mathrm{m}^{2}$ in 3 patients (6.3\%). None of them had family history of hepatocellular carcinoma. HBeAg was negative in all patients.

Liver stiffness measurements at the beginning and $12^{\text {th }}$ month of therapy were $7.4 \pm 3.8 \mathrm{kPa}$ and $6.2 \pm 2.9 \mathrm{kPa}$, respectively $(p=0.013)$. Decreasing in liver stiffness measurement was 0.95 $(0.30-2.37) \mathrm{kPa}$. Liver stiffness measurement was decreased in 17 patients (89.4\%) and increased in 2 patients (10.6\%).

At the beginning of therapy, 11 patients had osteopenia (57.9\%) and 8 patients had normal bone mineral density (43.1\%). At the $12^{\text {th }}$ month of therapy, 12 patients had osteopenia $(47.4 \%)$ and 10 patients had normal bone mineral density (52.6\%). The difference in bone mineral density between the beginning and the $12^{\text {th }}$ month of therapy was not statistically significant $(p=0.500)$.

There was not statistically significant difference in $\mathrm{qHBsAg}$ levels between the beginning and the $6^{\text {th }}$ month of therapy $(p=0.114)$. However, $q H B s A g$ levels showed a significantly $(p=0.003)$ decreasing as $9.1 \pm 18.5 \%$ at the $12^{\text {th }}$ month of therapy while comparing with the beginning.

There was statistically significant correlation between decrease in $\mathrm{qHBs}$ Ag levels and improvement in liver stiffness measurement (Table 1).

\section{Discussion}

Lamivudin has been used in the treatment of chronic HBV infection; however, resistance is an important problem due to low genetic barrier. Although it effectively suppress HBV replication in the short term, virological breaktrough and flare can occur due to mutations.

Therefore, lamivudin is no longer recommended as a first line therapy in the treatment of chronic HBV infection $(14,15,16)$.

The frequency of resistance to oral antivirals increases as the time goes by. After 5 years of therapy, resistance to lamivudin and adefovir reaches to $70 \%$ and $29 \%$, respectively.

Table 1. Correlation between $\mathrm{qHBsAg}$ and liver stiffness measurement

\begin{tabular}{|l|l|l|l|}
\hline \multicolumn{2}{|c|}{} & Fibroscan 1 & Fibroscan 2 \\
\hline \multirow{2}{*}{ HBsAg 0 } & $r$ & 0.511 & 0.502 \\
\cline { 2 - 4 } & $\mathrm{p}$ & 0.030 & 0.028 \\
\hline \multirow{2}{*}{ HBsAg 12 } & $\mathrm{r}$ & 0.492 & 0.476 \\
\cline { 2 - 4 } & $\mathrm{p}$ & 0.038 & 0.039 \\
\hline HbsAg: Hepatitis B surface antigen \\
\hline
\end{tabular}

Resistance to telbivudin was reported as $22 \%$ after 2 years. On the other hand, resistance to entecavir is only about $1.2 \%$ and resistance to tenofovir has not been reported yet $(13,17)$.

Besides effective and maintained suppression HBV replication, another goal of therapy is prevention of side effects. Because of low antiviral activity and low genetic barrier to resistance, lamivudin is no longer recommended as a first line therapy in the treatment of chronic HBV infection (18).

In a study by Marcellin et al. (19) 5-year TDF therapy resulted in histologic improvement in $87 \%$ patients and regression of fibrosis in $51 \%$ of patients. Only 9 of 641 patients developed side effect which had led to discontinuation of therapy (19). In the present study, histological improvement rate ocurred in 17 of 19 (89.7\%) of patients.

Routine follow up with liver biopsy is not recommended to monitör histological improvement due to its invasiveness and complications. Moreover, repeat liver biopsy result does not lead to therapy modification. Therefore, noninvasive tests are used to evaluate the efficacy of antivirals on histological activity. Of them, fibroscan is increasingly used to evaluate liver fibrosis.

In meta-analysis of 50 studies, the area under the receiver operating characteristic (ROC) curves of fibroscan to predict significant fibrosis (F2), advanced fibrosis (F3) and cirrhosis (F4) were 0,84 (95\% Cl, 0.82-0.86), $0.89(95 \% \mathrm{Cl}, 0.88-0.91)$ and 0.94 (95\% Cl, 0.93-0.95), respectively. As a result, transient elastography seems excellent in the prediction of cirrhosis and successfull in the prediction of advanced fibrosis, while there is variation in the prediction of significant fibrosis according to etiology of liver disease (20).

In an Asian metaanalysis, the area under the ROC curves of fibroscan to predict significant fibrosis (F2), advanced fibrosis (F3) and cirrhosis (F4) in chronic hepatitis B patients were 0.859 (95\% Cl, 0.857-0.860), 0.887 (95\% Cl, 0.886-0.887) and 0.929 (95\% Cl, 0.928-0.929), respectively (21). In another metaanalysis, Tsochatzis et al. (22) evaluated the diagnostic value of transient elastopgraphy. In this study, threshold liver stiffness measurement for F2, F3 and F4 fibrosis were 7, 9.5 and $12 \mathrm{kPa}$, respectively. Transient elastography had good sensitivity $[0,83(95 \% \mathrm{Cl} 0.79-$ 0.86)] and specifity [0.89 (95\% $\mathrm{Cl} 0.87-0.91)]$ in the prediction of cirrhosis; however, they concluded that it should be used with caution in thew prediction different fibrosis stages in daily practice because there was not approved threshold values (22). In a cross sectionel study, the thresholds in the prediction of F2, F3 and F4 fibrosis were 6,9, 7,9 and 9,6 $\mathrm{kPa}$, respectively (23). In the present study, liver fibrosis was improved significantly after 1 year therapy with TDF. Although the duration of treatment was short, the improvement in liver fibrosis is important and seems a valuable clue in the choise of antiviral agent.

HBsAg quantification has not been established in treatment monitorization yet. It was shown that there was correlation between cccDNA and intrahepatic HBV-DNA, and qHBsAg (24). In the present study, serum HBV DNA levels remained undetectable throughout therapy.

Moreover, qHBsAg levels decreased significantly after 1 year of TDF therapy. In a study, Pfefferkorn et al showed that qHBsAg level was reliable marker to establish inactive HBV carrier state (25). Tan et al. (26) showed that qHBsAg was not a reliable marker to 
differentiate HBeAg negative chronic hepatitis B and inactive HBV carrier state. Sali et al. (27) also found similar results. On the other hand, there are studies who showed opposite findings $(28,29)$. In the present study, decrease in qHBsAg levels supports TDF has favorable effects on cccDNA and intrahepatic HBV despite small number of patients.

\section{Study Limitations}

The most important limitations of our study are the small number of patients and the patients were evaluated without biopsy.

\section{Conclusion}

Potents antivirals as TDF should take place of lamivudin in the treatment of chronic hepatitis B. Significant decreasing in liver stiffness measurement and qHBsAg levels at long term can prevent the development of cirrhosis and hepatocellular carcinoma. There is need for studies made with large patient groups and in long term following up.

\section{Ethics}

Ethics Committee Approval: Local Ethic Committee approval was taken from the Kocaeli University Faculty of Medicine (approval number: 21.91016-2016/15.2).

Informed Consent: Verbal and written informed consent received.

Peer-review: Externally peer-reviewed.

\section{Authorship Contributions}

Surgical and Medical Practices: E.Y., F.G., Concept: M.S., G.Ş., Design: M.S., G.Ş., Data Collection or Processing: S.B.A., G.D., Analysis and/or Interpretation: S.B.A., M.K., Literature Search: E.Y., H.S., Writing: E.Y., M.K.

Conflict of Interest: All authors declare to have no conflict of interest.

Financial Disclosure: The authors declared that this study received no financial support.

\section{References}

1. Terrault NA, Lok ASF, McMahon BJ, Chang KMi, Hwang JP, Jonas MM, Brown Jr RS, Bzowej NH, Wong JB. Update on prevention, diagnosis, and treatment of chronic hepatitis B: AASLD 2018 hepatitis $B$ guidance. Corrections to AASLD guidelines on chronic hepatitis B. Hepatology. 2018;67:1560-1599.

2. Rodriguez $M$, Pascasio JM, Fraga $E$, Fuentes J, Priento $M$, Sánchez-Antolín G, Calleja JL, Molina E, García-Buey ML, Blanco MÁ, Salmerón J, Bonet ML, Pons JA, González JM, Miguel Ángel Casado MÁ, Jorquera F, TENOSIMP-B Research Group. Tenofovir vs lamivudine plus adefovir in chronic hepatitis B:TENOSIMP-B study. World J Gastroenterol. 2017;23:7459-7469.

3. Lai C, Chien R, Leung N, Chang TT, Guan R, Tai DI, Ng KY, Wu PC, Dent JC, Barber J, Stephenson SL, Gray DF. A one-year trial of lamivudine for chronic hepatitis B. Asia Hepatitis Lamivudine Study Group. N Engl Med. 1998;339:61-68.

4. Santantonio T, Mazzola M, lacovazzi T, Miglietta A, Guastadisegn A, Pastore G. Longterm follow-up of patients with anti-HBe/ HBV DNApositive chronic hepatitis B treated for 12 months with lamivudine. J Hepatol. 2000;32:300-306.

5. Hadziyannis SJ, Papatheodoridis GV, Dimou E, Laras A, Papaioannou C. Efficacy of long-term lamivudine monotherapy in patients with hepatitis $B$ e antigen-negative chronic hepatitis $B$. Hepatolgy. 2000;32:847-851.

6. Liaw YF, Sung JJ, Chow WC, Farrell G, Lee CZ, Yuen H, Tanwandee T, Tao OM, Shue K, Keene ON, Dixon JS, Fraser Gray D, Sabbat J, Cirrhosis Asian Lamivudine Multicentre Study Group. Lamivudine for patients with chronic hepatitis B and advanced liver disease. N Engl J Med. 2004;351:1521-1531.

7. Villeneuve JP, Condreay LD, Willems B, Pomier-Layrargues G, Fenyves D, Bilodeau M, Leduc R, Peltekian K, Wong F, Margulies M, Heathcote EJ. Lamivudine treatment for decompensated cirrhosis resulting from chronic hepatitis B. Hepatology. 2000;31:207-210.

8. Perrillo RP, Wright $T$, Rakela J, Levy G, Schiff E, Gish R, Martin P, Dienstag J, Adams P, Dickson R, Anschuetz G, Bell S, Condreay L, Brown N, Lamivudine North American Transplant Group et al. A multicenter United States-Canadian trial to assess lamivudine monotherapy before and after liver transplantation for chronic hepatitis B. Hepatology. 2001;33:424-432.

9. Ghany M, Liang TJ. Drug targets and molecular mechanisms of drug resistance in chronic hepatitis B. Gastroenterology 2007;132:1574-1585.

10. Van Bömmel $E$, Wünsche $T$, Schürmann D, Berg T. Tenofovir treatment in patients with lamivudine-resistant hepatitis B mutants strongly affects viral replication. Hepatology. 2002;36:507-508.

11. van Bömmel F, Zöllner B, Sarrazin C, Spengler U, Hüppe D, Möller B, Feucht HH, Wiedenmann B, Berg T. Tenofovir for patients with lamivudine-resistant hepatitis B virus (HBV) infection and high HBV DNA level during adefovir therapy. Hepatology. 2006;44:318325.

12. Marcellin P, Heathcote E.J, Buti M, Gane E, de Man RA, Krastev Z, Germanidis G, Lee SS, Flisiak R, Kaita K, Manns M, Kotzev I, Tchernev K, Buggisch P, Weilert F, Ovung Kurdas O, Shiffman ML, Trinh $\mathrm{H}$, Washington MK, Sorbel J, Anderson J, Snow-Lampart A, Mondou E, Quinn J, Rousseau F. Tenofovir disoproxil fumarate versus adefovir dipivoxil for chronic hepatitis B. N Eng J Med. 2008;359:2442-2455

13. EASL 2017 Clinical Practice Guidelines on the management of hepatitis B virus infection. J Hepatol. 2017;67:370-398.

14. Di Marco V, Marzano A, Lampertico P, Andreone P, Santantonio T, Almasio PL, Rizzetto M, Craxì A, Italian Association for the Study of the Liver (AISF) Lamivudine Study Group, Italy. Clinical outcome of $\mathrm{HBeAg}$-negative chronic hepatitis $\mathrm{B}$ in relation to virological response to lamivudine. Hepatology. 2004;40:883-891.

15. Lai CL, Chien RN, Leung NW, Chang TT, Guan R, Tai DI, Ng KY, Wu PC, Dent JC, Barber J, Stephenson SL, Gray DF. A-one year trial of lamivudine for chronic hepatitis. N Engl J Med. 1998;339:61-68.

16. Fasano $M$, Lampertico $P$, Marzano $A$, Marco VD, Niro GA, Brancaccio G, Marengo A, Scotto G, Brunetto MR, Gaeta GB, Rizzetto M, Angarano G, Santantonio T. HBV DNA suppression and $\mathrm{HBsAg}$ clearance in $\mathrm{HBeAg}$ negative chronic hepatitis $\mathrm{B}$ patients on lamivudine therapy for over 5 years. J Hepatol. 2012;56:1254-1258

17. Hadziyannis SJ, Sevastianos V, Rapti I, Vassşlopoulos D, Hadziyannis E. Sustained responses and loss of HBsAg in $\mathrm{HBeAg}$-negative patients with chronic hepatitis B who stop longterm treatment with adefovir. Gastroenterology. 2012;143:629-36.

18. Köksal I. Kronik hepatit B'de genel tedavi yaklașımı. In: Tabak F, Tosun S, eds. Viral Hepatit 2013. Ankara: Viral Hepatitle Savaşım Derneği; 2013:257-264.

19. Marcellin P, Gane E, Buti M, Afdhal N, Sievert W, Jacobson IM, Washington MK, Germanidis G, Flaherty JF, Schall RA, Bornstein JD, Kitrinos KM, Mani Subramanian G, McHutchison JG, Heathcote EJ. Regression of cirrhosis during treatment with tenofovir disoproxil fumarate for chronic hepatitis B: a 5-year open-label follow-up study. Lancet. 2013:381:468-475. 
20. Friedrich-Rust $M$, Ong MF, Martens $S$, Sarrazin C, Bojung J, Zeuzem S, Herrmann E. Performance of transient elastography for the staging of liver fibrosis: a meta-analysis. Gastroenterology. 2008; 134:960-974.

21. Chon YE, Choi EH, Song KJ, Park JY, Kim DY, Han KH, Chon CY, Ahn $\mathrm{SH}$, Up Kim S. Performance of transient elastography for the staging of liver fibrosis in patients with chronic hepatitis B: a metaanalysis. Plos one. 2012;7:e44930.

22. Tsochatzis EA, Gurusamy KS, Ntaoula S, Cholongitas E, Davidson $B R$, Burroughs AK. Elastography for the diagnosis of severity of fibrosis inchronic liver disease: a metaanalysis of diagnostic accuracy. J Hepatol. 2011;54:650-659.

23. Ferraioli G, Tinelli $C$, Bello BD, Zicchetti M, Lissandrin R, Gaetano Filice G, Filice C, Above E, Barbarini G, Brunetti E, Calderon W Di Gregorio M, Gulminetti R, Lanzarini P, Ludovisi S, Maiocchi L, Malfitano A, Michelone G, Minoli L, Mondelli M, Novati S, Patruno SFA, Perretti A, Poma G, Sacchi P, Zanaboni D, Zaramella M. Performance of liver stiffness measurements by transient elastography in chronic hepatitis. Wold J Gastroenterol. 2013;19:49-56.

24. Volz T, Lutgehetmann M, Wachtler P, Jacob A, Quaas A, Murray JM, Dandri M, Petersen J. Impaired intrahepatic hepatitis B virus productivity contributes to low viremia in most $\mathrm{HBeAg}$-negative patients. Gastroenterology. 2007;133:843-852.
25. Pfefferkorn M, Böhm S, Schott T, Deichsel D, Bremer CM Schröder K, Gerlich WH, Glebe D, Berg T, van Bömmel F. Quantification of large and middle proteins of hepatitis B virus surface antigen (HBsAg) as a novel tool for the identification of inactive HBV carriers. Gut. 2018;67:2045-2053.

26. Tan Z, Li M, Kuang X, Tang Y, Fan Y, Deng G, Wang Y, He D. Clinical implications of hepatitis $B$ surface antigen quantitation in the natural history of chronic hepatitis B virus infection. J Clin Virol. 2014;59:228-34.

27. Sali S, Sharafi H, Alavian SH, Alavian SM, Etesam F, Salimi S, Merza MA, Keshvari M. Can serum level of HBsAg differentiate HBeAg-negative chronic hepatitis B from inactive carrier state? Diagn Microbiol Infect Dis. 2015;82:114-119.

28. Martinot-Peignoux M, Lapalus $M$, Laouénan C, Lada O, NetooCardoso AC, Boyer N, Ripault MP, Carvalho-Filho R, Asselah T, Marcellin $\mathrm{M}$. Prediction of disease reactivation in asymptomatic hepatitis $B$ e antigen-negative chronic hepatitis B patients using baseline serum measurements of HBsAg and HBV-DNA. J Clin Virol. 2013;58:401-407.

29. Invernizzi F, Viganò $M$, Grossi G, Lampertico $P$ The prognosis and management of inactive HBV carriers. Liver Int. 2016;36 (Suppl 1):100-104 